\title{
AN INTEGRATED FUZZY AHP/DEA APPROACH FOR PERFORMANCE EVALUATION OF TERRITORIAL UNITS IN TURKEY
}

\author{
Ahmet ÇALIK $^{1^{*}}$, Nimet YAPICI PEHLIVAN ${ }^{2}$, Cengiz KAHRAMAN ${ }^{3}$ \\ ${ }^{1}$ International Trade and Logistics, KTO Karatay University, Konya 42020, Turkey \\ ${ }^{2}$ Statistics, Selçuk University, Konya 42250, Turkey \\ ${ }^{3}$ Industrial Engineering, Istanbul Technical University, İstanbul 34367, Turkey
}

Received 20 April 2015; accepted 26 August 2016

\begin{abstract}
Due to the differences between regions and sub-regions in the countries, some problems come out especially in economic and social life. The issue of differences of regions has been widely implemented to evaluate the economic performance of Turkey in many disciplines. The objective of this paper is to evaluate the efficiency of 26 sub-regions of NUTS-2 classification using integration Fuzzy Analytic Hierarchy Process (FAHP) with Data Envelopment Analysis (DEA). The integrated FAHP/DEA method comprises two stages. In the first stage, linguistic terms are used to determine the decision makers' opinion and are converted to quantitative forms by using FAHP methods. Subsequently, in the second stage, DEA method is applied to obtain relative efficiency of sub-regions in Turkey. The integrated FAHP/DEA method is illustrated with a real case study.
\end{abstract}

Keywords: Fuzzy Analytic Hierarchy Process, Data Envelopment Analysis, NUTS-2 classification.

JEL Classification: D81, P48, C44, D70.

\section{Introduction}

In the 21 st century, a major change, that affects every aspects of life, has taken place, this process is called globalization and it requires continuous renewal and variation due to the occurrence of transformations. As a result of globalization, innovations and developments have increased; furthermore, efficiency and productivity concepts have gained importance. Development differences between regions are one of the important problems that raise attention of the most researchers in the world. As well as, there are developed and less developed countries in the world; there are also regions that are developed and less developed, within those countries. Differences between these regions affect the country in every aspect and governments want to reduce the differences between those regions.

*Corresponding author. E-mail: ahmetcalik51@gmail.com 
In regards to economic and social criteria, Turkey has important differences between the regions. These differences among regions have lead into serious problems. For the industrial sector, the western provinces of the country are more effective than the middle and eastern provinces. Turkey has the world's 18th largest nominal Gross Domestic Product (GDP), and 17th largest GDP by Purchasing Power Parity (PPP). The country is a founding member of the Organization for Economic Co-operation and Development (OECD) and the G-20 major economies (Wikipedia 2014). Despite economic crises Turkey had, Turkey's economy has taken big steps towards being a reliable economy in the last decade. In 2010, the agricultural sector accounts for $9 \%$ of GDP, while the industrial sector accounts for $26 \%$ and the services sector accounts for 65\% (CIA 2010).

The aim of this study is to propose an integrated FAHP/DEA method for the performance evaluation of the sub-regions in Turkey. The performance evaluation of the subregions is an essentially MCDM problem, which involves both qualitative and quantitative criteria. One of the MCDM approaches FAHP, can be used to evaluate both qualitative and quantitative criteria. However, if number of criteria and alternatives increase, decision makers cannot obtain consistent evaluations due to the large scale dimension of pairwise comparison matrices. To overcome these difficulties we integrated FAHP methods with DEA models. In addition, there is no study considering the performance evaluation of regions or sub-regions in Turkey. Most researchers have been focused on specific studies such as operational performance of the thermal power plant, performance of manufacturing firms, and evaluation of government investments in higher education and so on. To address this gap, we measure the performance evaluation of sub-regions in Turkey by integrated FAHP/DEA method.

The remainder of this study is organized as follows: Section 1 deals with an overview of the FAHP methods, DEA models and integrated FAHP-DEA method. Section 2 discusses the details of the proposed FAHP-DEA methodology. Section 3 shows a real case study that provides an application of the proposed FAHP/DEA method. Section 4 presents the conclusion of the study.

\section{Literature review}

Since the 1960s, Multi-Criteria Decision Making (MCDM) has been a popular decisionmaking tool including quantitative and qualitative criteria/factors. The MCDM methods divided into two main approaches: Multi Attribute Decision Making (MADM) methods and Multi Objective Decision Making (MODM) methods. MADM problems contain the finite set of alternatives, whereas MODM problems contain the infinite set of alternatives (Kahraman 2008). The MCDM method includes following stages: (1) determination of the alternatives/criteria, (2) evaluation of the alternatives according to the criteria, (3) an evaluation score of the alternatives on the criteria, and (4) determination of criteria weights (Thokala, Duenas 2012). Fuzzy MCDM methods have been used to assess alternatives according to the several criteria by decision maker(s). Therefore, fuzzy MCDM methods are a growing area that integrates MCDM methods and fuzzy sets. Various approaches have been proposed to solve MCDM and fuzzy MCDM problems (Celik et al. 2015; Kahraman et al. 2015). In recent years, many review articles have been published on methods of MCDM 
and fuzzy MCDM, such as Ho (2008), Zavadskas and Turskis (2011), Liou and Tzeng (2012), Zavadskas et al. (2014b), Mardani et al. (2015), Kahraman et al. (2015) and Celik et al. (2015). Several studies have carried out using the MCDM and fuzzy MCDM methods in different fields, construction (Brauers et al. 2013; Zavadskas et al. 2014a), energy (Abid, Bahloul 2011; Erol, Kılkış 2012), supplier selection (Govindan et al.2013; Shaw et al. 2012), management (Baležentis, A., Baležentis, T. 2011; Liu et al. 2012).

\subsection{Fuzzy Analytic Hierarchy Process Method}

Analytic Hierarchy Process (AHP) proposed by Saaty (1980) method is an extensively used MCDM method to help decision makers and researchers since 1980s (Vaidya, Kumar 2006). Although AHP method has been widely used, it cannot really reflect the human thinking. In real world problems, decision making process could be consisted of uncertain situations. To overcome uncertainties, fuzzy set theory is combined with AHP and several FAHP methods are proposed by various authors. The first study is proposed by Van Laarhoven and Pedrycz (1983) using triangular fuzzy numbers and logarithmic regression method. Buckley (1985) extended AHP with trapezoidal fuzzy numbers and used the geometric mean method to derive fuzzy weights. Chang (1996) presented extent analysis method by using triangular fuzzy numbers. Mikhailov (2002) presented fuzzy preference programming method which based on $\alpha$-cuts decomposition of the fuzzy judgements. Mikhailov (2003) proposed a non-linear method that decision makers can find crisp values using triangular fuzzy numbers. Applications of FAHP methods in different fields can be found the literature, such as engineering (Akadiri et al. 2013; Pan 2008; Tansel İç et al. 2013), management and business (Durán 2011; Lin et al. 2009), science and technology (Gao, Hailu 2012; Najafi et al. 2014). In recent years, AHP methods and FAHP methods have been applied for many studies regarding to Turkey. Ecer (2014) proposed a hybrid approach based on AHP and COPRAS-G to assess the website quality of banks in Turkey. Taylan et al. (2014) presented a novel tool to evaluate the construction projects by by fuzzy AHP and fuzzy TOPSIS methodologies. Kahraman et al. (2013) used FAHP to take the criteria into account in government investment in higher education in Turkey. Baysal et al. (2015) evaluated the ranking of the nine sub-municipal projects in Konya, Turkey with FAHP. Deveci et al. (2015) compared the performance of fuzzy MCDM methods for solving the carbon dioxide geological storage location selection problem in Turkey.

\subsection{Data Envelopment Analysis Method}

Data envelopment analysis (DEA) initially proposed by Charnes et al. (1978) and Banker et al. (1984) is a linear programming approach to obtain the relative efficiencies of decision making units (DMUs). DEA methods have been extensively used for many disciplines in operational research and decision making problems: Shafer and Byrd (2000) measured the relative efficiency of organizational investments in information technology, Camanho and Dyson (2005) and Chen et al. (2005) investigated the bank efficiency, Johnes (2006) and Nazarko and Šaparauskas (2014) evaluated the efficiency of higher education institutions, Ramanathan (2006b) handled comparative performance analysis of governments, Sun et al. 
(2012) measured regional environmental performance of eight western regions in China, Wang et al. (2013) computed the energy and environmental efficiency of 29 administrative regions of China. The performance of countries are handled with different DEA models by various authors (Kou et al. 2016; Meng et al. 2014; Vlontzos et al. 2014; Yang et al. 2016). Also, DEA method is applied in different research areas in Turkey: Sarıca and Or (2007) applied the DEA method for the performance evaluation of electricity generation plants in Turkey. Köksal and Aksu (2007) compared the 24 A-Group Travel agencies in Turkey with DEA method. Düzakın, E. and Düzakın, H. (2007) applied the slacks based model of DEA to measure performance of manufacturing firms in Turkey. Sözen et al. (2010) calculated the efficiency of thermal power plants in Turkey by using DEA method.

\subsection{Applications of Integrated Fuzzy Analytic Hierarchy Process (FAHP) and Data Envelopment Analysis Method}

In the literature, there have been limited on integration of FAHP and DEA methods. Sinuany-Stern et al. (2000) presented two-stage ranking model, AHP/DEA, for ranking units. Yang and Kuo (2003) applied AHP/DEA methodology for solving a multiple objective layout design problem. Saen et al. (2005) measured relative weights slightly nonhomogeneous DMUs by AHP and relative efficiency of DMUs by chance-constrained DEA. Ertay et al. (2006) combined DEA and AHP methods to solve facility layout design (FLD) problem. Ramanathan (2006a) proposed Data Envelopment Analytic Hierarchy Process (DEAHP) method, which is a hybrid methodology of DEA and AHP. Sevkli et al. (2007) applied the DEAHP methodology developed by Ramanathan (2006a) in supplier selection of well-known Turkish company operating in appliance industry. Korpela et al. (2007) handled warehouse operator selection with integrated AHP-DEA approach. Giokas and Pentzaropoulos (2008) compared and ranked of 30 OECD members with two quantitative instruments as AHP and DEA. Azadeh et al. (2008) proposed an integrated model by integration of DEA, AHP and computer simulation for railway system improvement and optimization. Wang et al. (2008) used an integrated AHP-DEA methodology for evaluating bridge risks structures. Tseng and Lee (2009) investigated human resource practices and their influence on organizational performance by AHP/DEA model. Che et al. (2010) proposed a FAHP-DEA methodology for solving bank loan decision problems. Lee et al. (2010) used an integrated fuzzy AHP-DEA to measure the relative efficiency of the national hydrogen energy technology development. Lee et al. (2011) measured the relative efficiency of hydrogen energy technologies with integrated fuzzy AHP/DEA approach. Azadeh et al. (2011) applied an integrated AHP and DEA method to evaluate personnel productivity in banking institutions. Lin et al. (2011) evaluated the economic performance of local governments in China by integrated DEA/AHP model. Lee et al. (2013) developed an integrated two-stage MCDM approach. In the approach, relative weights of criteria are calculated by FAHP method and the relative efficiency of energy technologies are measured by DEA method. Do and Chen (2014) applied the FAHP and the DEA model with an assurance region (AR) for measuring the efficiency scores of universities. Kumar et al. (2015) used a 


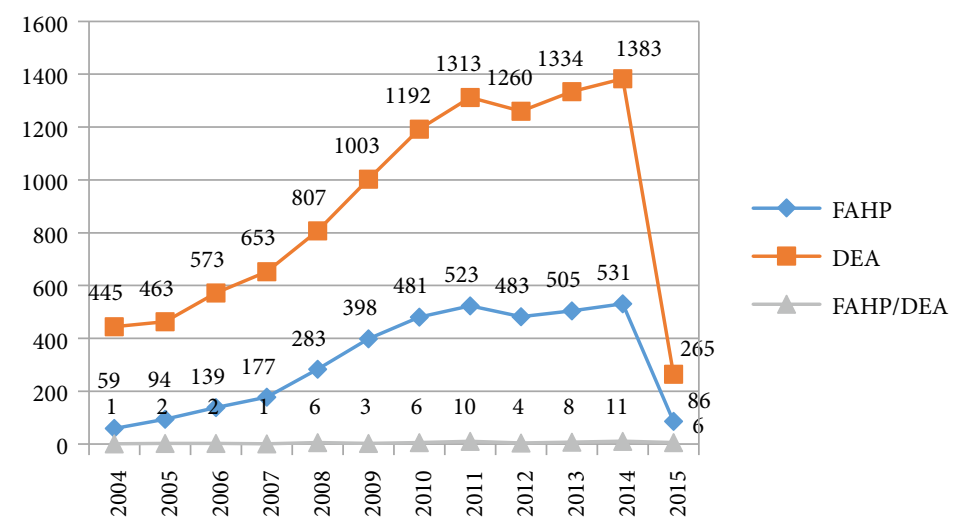

Figure 1. Distribution of the FAHP, DEA and FAHP/DEA publications (2004-2015)

hybrid FAHP/DEA model for benchmarking the quality of service in Indian mobile sector.

Figure 1 presents a comprehensive review in this field despite the vast number of published papers according to the Scopus database Publications on FAHP and DEA have been used more extensively than integrated FAHP/DEA for the years between 2004 and 2015. Although there are some research studies to handle the Turkey's performance in different fields by FAHP and/or DEA, there are no studies on performance evaluation of sub-regions in Turkey. According to the literature review, an integrated FAHP/DEA approach can be used for obtaining the performance evaluation of sub-regions in Turkey.

\section{Proposed methodology}

Two main steps are considered to apply the proposed methodology: The first step starts with defining the goal of the problem. In the second step, a data collection should be performed to define the qualitative and quantitative variables. After the data collection, the qualitative variables should be converted to quantitative ones using different FAHP methods, i.e. FAHP-EA, FAHP-GM, FAHP-FPP. After that, these weights are combined with the quantitative variables and finally, ranking the DMUs are obtained by DEA method. The hierarchical framework of the proposed methodology illustrated in Figure 2.

\subsection{Fuzzy Analytic Hierarchy Process}

Analytic Hierarchy Process (AHP) which is a MCDM method, have used a hierarchical structure to represent a decision problem. In the method, weights of the criteria and alternatives are produced according to the decision makers' opinions. FAHP is a fuzzy extension of AHP in order to solve MCDM problems under fuzzy environment. Judgments and preferences of decision makers are affected by uncertainty, so that the use of definite and precise numbers in linguistic judgments is not very reasonable (Calabrese et al. 2013). 


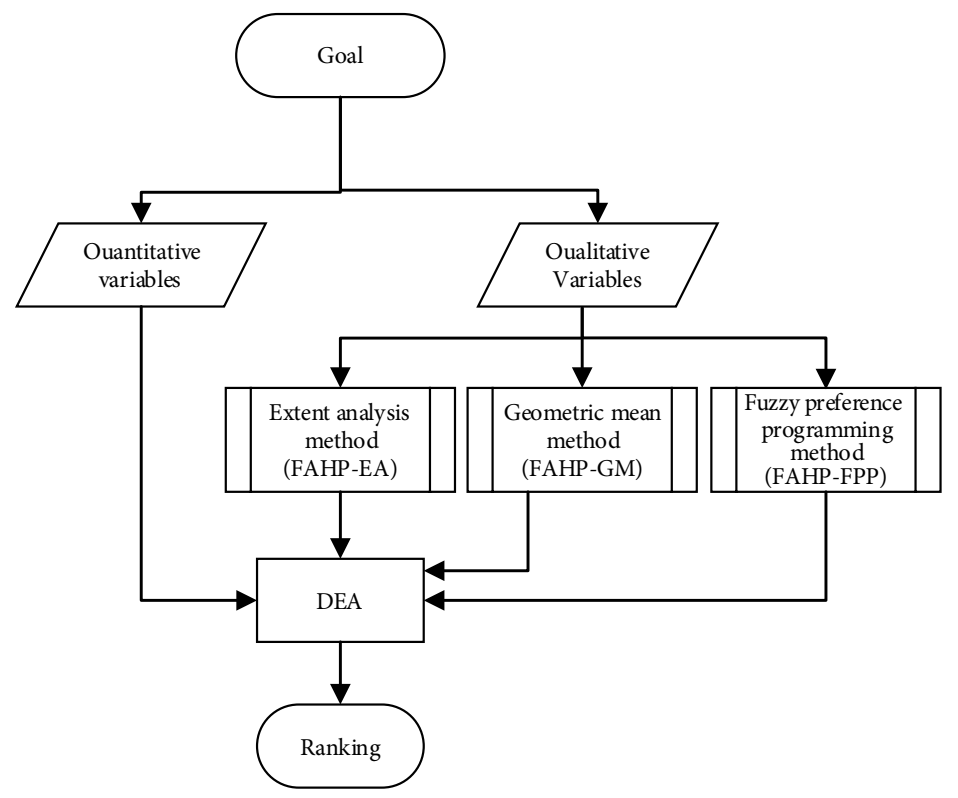

Figure 2. Hierarchical framework of the proposed methodology

\subsubsection{Extent analysis method (FAHP-EA)}

Chang (1996) proposed Extent Analysis method (FAHP-EA) by using triangular fuzzy numbers for pairwise comparison scale. In the method, fuzzy synthetic extent values of the pairwise comparisons are computed and then crisp weights are calculated (Büyüközkan et al. 2008; Kahraman et al. 2006).

Step 1: The value of fuzzy synthetic extent with respect to the $i^{\text {th }}$ object is defined as:

where:

$$
S_{i}=\sum_{j=1}^{m} M_{g_{i}}^{j}\left[\sum_{i=1}^{n} \sum_{j=1}^{m} M_{g_{i}}^{j}\right]^{-1},
$$

$$
\begin{gathered}
\sum_{j=1}^{m} M_{g_{i}}^{j}=\left(\sum_{j=1}^{m} l_{j}, \sum_{j=1}^{m} m_{j}, \sum_{j=1}^{m} u_{j}\right) ; \\
{\left[\sum_{i=1}^{n} \sum_{j=1}^{m} M_{g_{i}}^{j}\right]^{-1}=\left(\frac{1}{\sum_{i=1}^{n} u_{i}}, \frac{1}{\sum_{i=1}^{n} m_{i}}, \frac{1}{\sum_{i=1}^{n} l_{i}}\right) .}
\end{gathered}
$$


Step 2: To compare of the fuzzy numbers, the degree of possibility of $S_{2} \geq S_{1}$ is defined as:

$$
\begin{aligned}
V\left(S_{2} \geq S_{1}\right)= & \sup _{y \geq x}\left[\min \left(\mu_{S_{1}(x)}, \mu_{S_{2}(y)}\right)\right]=h g t\left(S_{1} \cap S_{2}\right)=\mu_{S_{2}(d)}= \\
& \left\{\begin{array}{l}
1, \text { if } m_{2} \geq m_{1} \\
0, l_{1} \geq u_{2} \\
\frac{\left(l_{1}-u_{2}\right)}{\left(m_{2}-u_{2}\right)-\left(m_{1}-l_{1}\right)}, \text { otherwise, }
\end{array}\right.
\end{aligned}
$$

where: $S_{1}=\left(l_{1}, m_{1}, u_{1}\right)$ and $S_{2}=\left(l_{2}, m_{2}, u_{2}\right)$ and $d$ is the ordinate of the highest intersection point $D$ between $\mu_{S_{1}}$ and $\mu_{S_{2}}$ (see Figure 3 ).

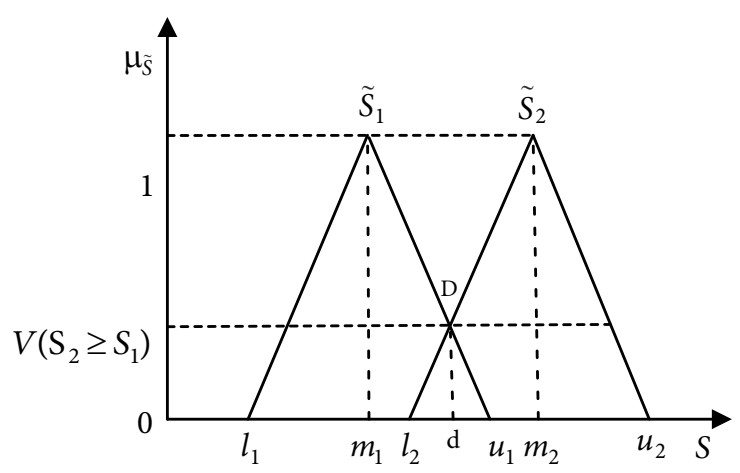

Figure 3. The intersection between $\tilde{S}_{1}$ and $\tilde{S}_{2}$

Step 3: The degree of possibility for a fuzzy number greater than $k$ fuzzy $S_{i},(i=1,2, \ldots, k)$ numbers is defined by the following equations:

$$
V\left(S \geq S_{1}, S_{2}, \ldots, S_{k}\right)=\min V\left(S \geq S_{i}\right), \quad i=1,2, \ldots, k .
$$

Assume that,

$$
d^{\prime}\left(A_{i}\right)=\min V\left(S_{i} \geq S_{k}\right), k=1,2, \ldots, n ; k \neq i .
$$

Then the weight vector is defined by

$$
W^{\prime}=\left(d^{\prime}\left(A_{1}\right), d^{\prime}\left(A_{2}\right), \ldots, d^{\prime}\left(A_{n}\right)\right)^{T} .
$$

Step 4: After normalization, the normalized weight vectors can be defined as follows:

$$
W=\left(d\left(A_{1}\right), d\left(A_{2}\right), \ldots, d\left(A_{n}\right)\right)^{T},
$$

where: $W$ is not a fuzzy number (Chang 1996; Kahraman et al. 2006).

\subsubsection{Geometric mean method (FAHP-GM)}

The Geometric Mean Method (FAHP-GM) which is extension of AHP, was first employed by Buckley (1985) to derive fuzzy weights and performance scores. The method can be summarized as follows: 
Step 1: A fuzzy pairwise comparison matrix $\left(\tilde{A}=\left[\mathrm{a}_{i j}\right]\right)$ is given by:

$$
\tilde{A}=\left[\begin{array}{ccccc}
1 & \cdots & \tilde{a}_{1 j} & \cdots & \tilde{a}_{1 n} \\
\vdots & & \vdots & & \vdots \\
\tilde{a}_{i 1} & \cdots & 1 & \cdots & \tilde{a}_{i n} \\
\vdots & & \vdots & & \vdots \\
\tilde{a}_{n 1} & & \tilde{a}_{n j} & \cdots & 1
\end{array}\right]=\left[\begin{array}{ccccc}
1 & \cdots & \tilde{a}_{1 j} & \cdots & \tilde{a}_{1 n} \\
\vdots & & \vdots & & \vdots \\
1 / \tilde{a}_{i 1} & \cdots & 1 & \cdots & \tilde{a}_{i n} \\
\vdots & & \vdots & & \vdots \\
1 / \tilde{a}_{n 1} & & 1 / \tilde{a}_{n j} & \cdots & 1
\end{array}\right],
$$

where $\tilde{a}_{i j}=\left(l_{i j}, m_{i j}, u_{i j}\right)$ is a triangular fuzzy numbers $(i=1,2, \ldots, n, j=1,2, \ldots, m)$

Step 2: The fuzzy weight matrix and the fuzzy weights of each criterion/alternative calculated as

$$
\begin{gathered}
\tilde{a}_{i}=\left(\tilde{a}_{i 1} \otimes \tilde{a}_{i 2} \otimes \ldots \otimes \tilde{a}_{i n}\right)^{1 / n} ; \\
\tilde{w}_{i}=\tilde{a}_{i} \otimes\left(\tilde{a}_{1} \oplus \tilde{a}_{2} \oplus \ldots \oplus \tilde{a}_{n}\right)^{-1},
\end{gathered}
$$

where: $\tilde{a}_{i}$ is the geometric mean of fuzzy comparison value; $\tilde{w}_{i}$ is a triangular fuzzy number and it should be defuzzified by any defuzzification method (Tzeng, Huang 2011).

\subsubsection{Fuzzy preference programming method (FAHP-FPP)}

Fuzzy preference programming method (FAHP-FPP) proposed by Mikhailov (2002) for deriving weights from fuzzy comparison judgements. The linear programming based method is formulated as follows:

$$
\begin{aligned}
& \operatorname{Max} \lambda \\
& d_{k} \lambda+R_{k} w \leq d_{k} \\
& \sum_{i=1}^{n} w_{i}=1, w_{i}>0, i=1,2, \ldots, n, k=1,2, \ldots, 2 m,
\end{aligned}
$$

where: $\lambda$ denotes the degree of satisfaction is a tolerance parameter, $d_{k}$ is a tolerance parameter (Mikhailov 2003).

In Eq. (7):

$$
R_{k} w=\left\{\begin{array}{l}
w_{i}-w_{j} u_{i j}(\alpha) \tilde{\leq} 0 \\
-w_{i}+w_{j} l_{i j}(\alpha) \tilde{\leq} 0
\end{array}\right.
$$

and its membership function is defined as

$$
\mu_{k}\left(R_{k} w\right)=\left\{\begin{array}{l}
1-\frac{R_{k} w}{d_{k}}, R_{k} w \leq d_{k} \\
0, R_{k} w \geq d_{k} .
\end{array}\right.
$$

In Eq. (8), the priority ratios at each $\alpha$-cut level should satisfy $l_{i j}(\alpha) \leq w_{i} / w_{j} \leq u_{i j}(\alpha)$ and the bounds of $\alpha$-cut the intervals are defined:

$$
\begin{aligned}
& l_{i j}(\alpha)=\alpha\left(m_{i j}-l_{i j}\right)+l_{i j}, \\
& u_{i j}(\alpha)=\alpha\left(m_{i j}-u_{i j}\right)+u_{i j} .
\end{aligned}
$$




\subsection{Data Envelopment Analysis (DEA)}

Data Envelopment Analysis (DEA) is a linear programming based method to evaluate the relative efficiency of DMUs. There are four basic DEA models in the literature: Charnes, Cooper, Rhodes (CCR) model, Banker, Charnes, Cooper (BCC) model, the multiplicative model and additive model. Also DEA model can be divided according to the orientation: output-oriented DEA models or input-oriented DEA models (Azadeh et al. 2011). The input oriented CCR model and the output oriented CCR model is given in Eq. (11) and Eq. (12):

$$
\begin{aligned}
\operatorname{Max} & z= \\
& \sum_{r=1}^{s} u_{r} y_{r 0}, \\
& \sum_{r=1}^{s} u_{r} y_{r j}-\sum_{i=1}^{m} v_{i} x_{i j} \leq 0 \quad j=1, \ldots, n, \\
& \sum_{i=1}^{m} v_{i} x_{i o}=1, \\
& v_{i} \geq 0, \quad i=1, \ldots, m, \\
& u_{r} \geq 0, r=1, \ldots, s ; \\
\operatorname{Min} q= & \sum_{i=1}^{m} v_{i} x_{i o}, \\
& \sum_{i=1}^{m} v_{i} x_{i j}-\sum_{r=1}^{s} u_{r} y_{r j} \leq 0 \quad j=1,2, \ldots, n, \\
& \sum_{r=1}^{s} u_{r} y_{r o}=1, \\
& v_{i} \geq 0 \quad i=1, \ldots, m, \\
& u_{r} \geq 0 \quad r=1, \ldots, s .
\end{aligned}
$$

In the Eq. (11) and Eq. (12), $y_{r j}$ is the value of output $r$ for the DMU $j ; x_{i j}$ is the value of input $i$ for the DMU $j ; u_{r}, r=1,2, \ldots, s$ is the weight given to the output $r$ and $v_{i}, i=1$, $2, \ldots, m$ is the weight given to the input $i$.

If the constraint $\sum_{j=1}^{n} \lambda_{j}=1$ is added to the CCR model, it is known as BCC (Banker et al. 1984) model. The input oriented and output oriented BCC models are formulated as follows, respectively (Cooper et al. 2004).

$$
\begin{aligned}
\operatorname{Max} z= & \sum_{r=1}^{s} u_{r} y_{r o}-u_{o}, \\
& \sum_{r=1}^{s} u_{r} y_{r j}-\sum_{i=1}^{m} v_{i} x_{i j}-u_{o} \leq 0 \quad j=1,2, \ldots, n,
\end{aligned}
$$




$$
\begin{aligned}
& \sum_{i=1}^{m} v_{i} x_{i o}=1, \\
& u_{o} \text { free insign, } \\
& v_{i} \geq \varepsilon, i=1,2, \ldots, m, \\
& u_{r} \geq \varepsilon, r=1,2, \ldots, s ; \\
\operatorname{Min} q= & \sum_{i=1}^{m} v_{i} x_{i o}-v_{o}, \\
& \sum_{r=1}^{s} u_{r} y_{r o}=1, \\
& \sum_{i=1}^{m} v_{i} x_{i j}-\sum_{r=1}^{s} \mu_{r} y_{r j}-v_{o} \geq 0 j=1,2, \ldots, n, \\
& v_{o} \text { free insign }, \\
& v_{i} \geq \varepsilon, i=1,2, \ldots, m, \\
& \mu_{r} \geq \varepsilon, r=1,2, \ldots, s .
\end{aligned}
$$

In Eq. (13) and Eq. (14), $u_{o}$ indicates returns to scale (Cooper et al. 2000).

\section{A real case study}

In this section, a case study is handled to specify the efficiency of NUTS-2 sub-regions in Turkey. A survey was conducted for the years 2009 and 2010 in order to perform the integrated FAHP/DEA method. Framework of the study is shown in Figure 4.

\subsection{Variables and Decision Making Units}

In this study, qualitative and quantitative variables were collected related to sub-regions of Turkey and shown in Table 1. In the FAHP analysis, three qualitative variables are used and other nine quantitative variables are used for DEA analysis.

Table 1. Quantitative and qualitative variables used in the study

\begin{tabular}{ll}
\hline \multicolumn{1}{c}{ Quantitative variables } & Qualitative variables \\
\hline Crude suicide rate & Security \\
\hline College or university graduate rate & Earthquake risk \\
\hline Exports per capita & Tourism \\
\hline Value of crop production per capita & \\
\hline Per capita electricity consumption & \\
\hline Number of enterprises & \\
\hline Literacy rate & \\
\hline Imports per capita & \\
\hline Number of benefit from the libraries thousands per capita &
\end{tabular}




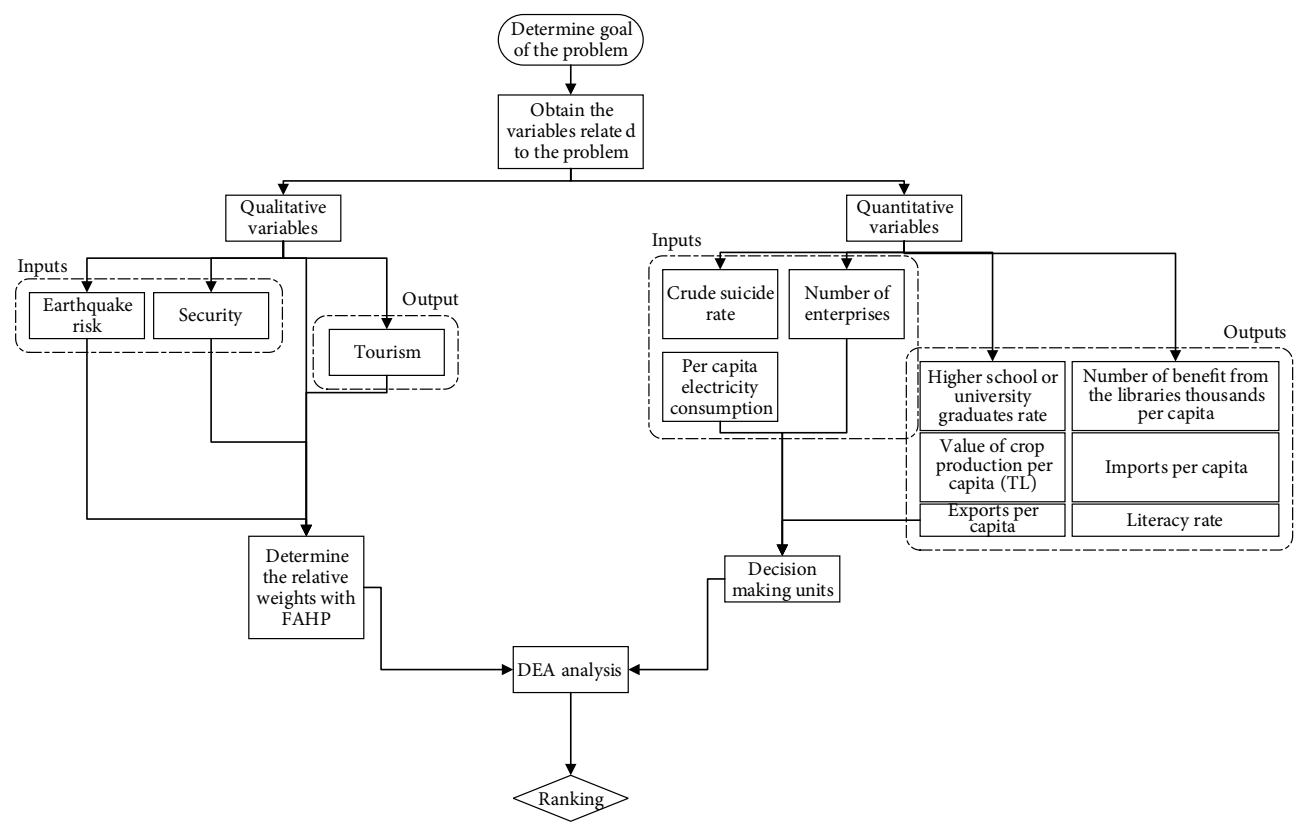

Figure 4. Framework of the integrated FAHP/DEA method

Turkey was divided into 12 regions and 26 sub-regions and 81 provinces according to the "Nomenclature of Territorial Units for Statistics (NUTS)" classification which is developed by the European Union (EU) to obtain a standard between for statistical purposes. The NUTS-2 classifications of Turkey and its related sub-regions are given in Table 2 (Wikipedia 2015).

Table 2. NUTS-2 sub-regions of Turkey

\begin{tabular}{cl}
\hline NUTS-2 classification & \multicolumn{1}{c}{ Sub-regions } \\
\hline TR10 & Istanbul \\
\hline TR21 & Tekirdağ, Edirne, Kırklareli \\
\hline TR22 & Balıkesir, Çanakkale \\
\hline TR31 & İzmir \\
\hline TR32 & Aydın, Denizli, Muğla \\
\hline TR33 & Manisa, Afyon, Kütahya, Uşak \\
\hline TR41 & Bursa, Eskişehir, Bilecik \\
\hline TR42 & Kocaeli, Sakarya, Düzce, Bolu, Yalova \\
\hline TR51 & Ankara \\
\hline TR52 & Konya, Karaman \\
\hline TR61 & Antalya, Isparta, Burdur \\
\hline TR62 & Adana, Mersin \\
\hline TR63 & Hatay, Kahramanmaraş, Osmaniye \\
\hline TR71 & Kırıkkale, Aksaray, Niğde, Nevşehir, Kırşehir \\
\hline
\end{tabular}


End of Table 2

\begin{tabular}{cl}
\hline NUTS-2 classification & \multicolumn{1}{c}{ Sub-regions } \\
\hline TR72 & Kayseri, Sivas, Yozgat \\
\hline TR81 & Zonguldak, Karabük, Bartın \\
\hline TR82 & Kastamonu, Çankırı, Sinop \\
\hline TR83 & Samsun, Tokat, Çorum, Amasya \\
\hline TR90 & Trabzon, Ordu, Giresun, Rize, Artvin, Gümüşhane \\
\hline TRA1 & Erzurum, Erzincan, Bayburt \\
\hline TRA2 & Ağrı, Kars, Iğdır, Ardahan \\
\hline TRB1 & Malatya, Elazı̆̆, Bingöl, Tunceli \\
\hline TRB2 & Van, Muş, Bitlis, Hakkari \\
\hline TRC1 & Gaziantep, Adıyaman, Kilis \\
\hline TRC2 & Şanlıurfa, Diyarbakır \\
\hline TRC3 & Mardin, Batman, Şırnak, Siirt \\
\hline
\end{tabular}

\subsection{FAHP analysis}

In the solution process, the weights of the qualitative variables are determined by FAHP methods. A committee was constituted to perform FAHP methods in order to make a comprehensive decision. Thus, a meeting was organized with a committee consists of four experts for evaluating the qualitative variables: an administrator and an expert working at Konya regional office of TUIK, and two academicians (a statistician an industrial engineer) are chosen for the determination and evaluation of qualitative variables. Committee who have more than three years' knowledge in this field was constituted according to their profession. The experts used a nine point scale for the evaluation of the criteria as given in Table 3.

Table 3. Fuzzy evaluation scale for FAHP (Kaya, Kahraman 2011)

\begin{tabular}{lclc}
\hline \multicolumn{1}{c}{ Linguistic terms } & Fuzzy scale & \multicolumn{1}{c}{ Linguistic terms } & Fuzzy scale \\
\hline Absolutely strong (AS) & $(2,5 / 2,3)$ & Slightly weak (SW) & $(2 / 3,1,1)$ \\
\hline Very strong (VS) & $(3 / 2,2,5 / 2)$ & Fairly weak (FW) & $(1 / 2,2 / 3,1)$ \\
\hline Fairly strong (FS) & $(1,3 / 2,2)$ & Very weak (VW) & $(2 / 5,1 / 2,2 / 3)$ \\
\hline Slightly strong (SS) & $(1,1,3 / 2)$ & Absolutely weak (AW) & $(1 / 3,2 / 5,1 / 2)$ \\
\hline Equal (E) & $(1,1,1)$ & & \\
\hline
\end{tabular}

The fuzzy comparison matrices of qualitative criteria were obtained by questionnaire. The pair-wise comparisons are obtained by using triangular fuzzy evaluation scale given in Table 3. The fuzzy pair-wise comparisons matrices of qualitative criteria, Security, Earthquake Risk, Tourism, are given in detailed in (Çalık 2012). After the fuzzy pair-wise comparisons matrices are constructed, the criteria weights are calculated with using FAHP-EA, FAHP-GM and FAHP-FPP methods. The solution algorithms of the considered methods are coded in MATLAB R2010a for obtaining the criteria weights. The weights of the each alternative, i.e. DMUs, with respect to the criteria are given in Table 4. 


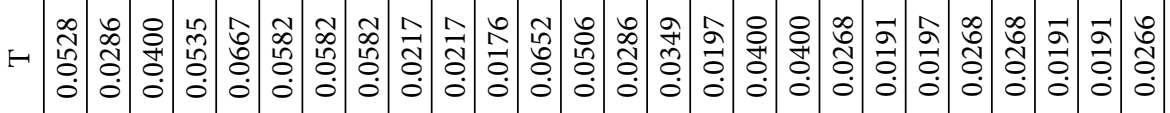

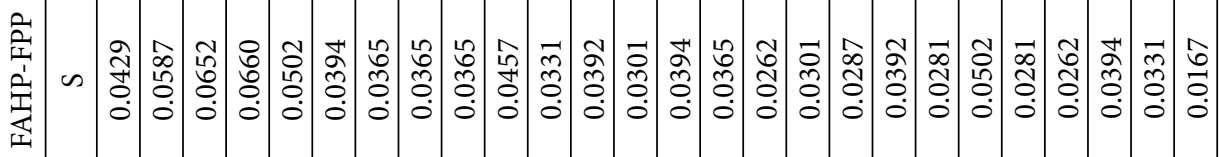

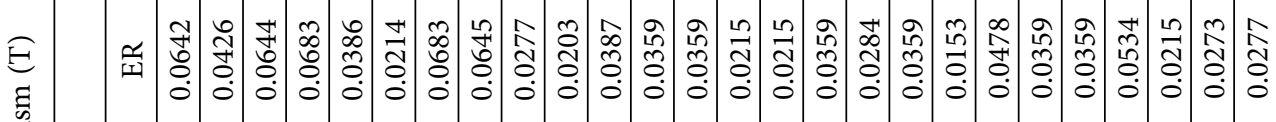

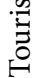

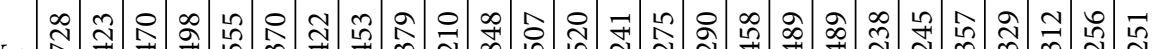

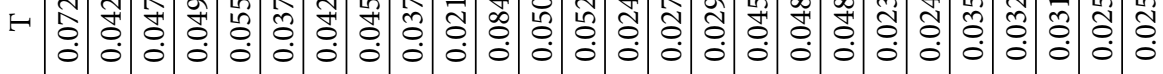

空

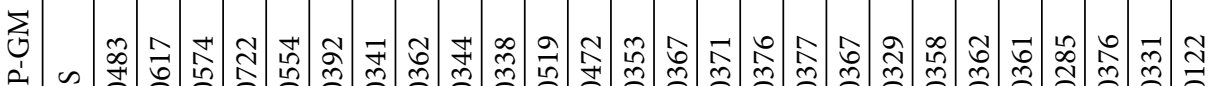

空

步 空

政

ב

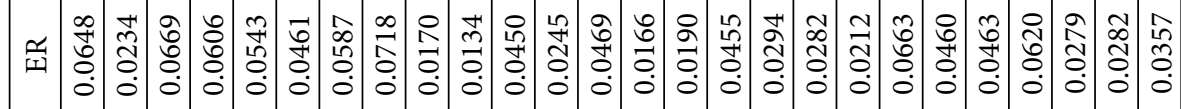

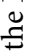

우

4

ڤ్

芳

a

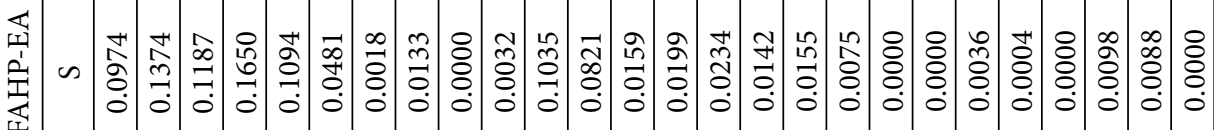

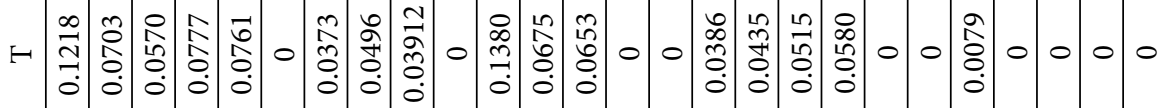
क

누

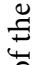

$\stackrel{0}{:}$

을

至

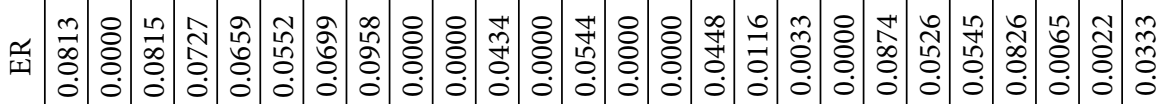

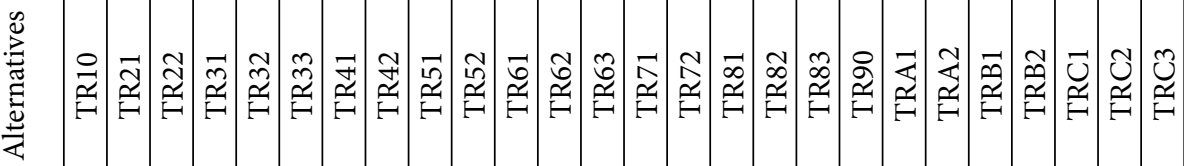


According to the Earthquake Risk (ER) in Table 4, TR42 is the most dangerous subregion computed by FAHP-EA and FAHP-GM whereas TR41 is the most dangerous region with respect to FAHP-FPP. TR31 has the highest priority according to the FAHP-EA, FAHP-GM and FAHP-FPP with respect to Security (S). Also, TR21 seems to be the most dangerous region for Security (S) criteria. TR61 and TR10 are the most attractive subregions computed by FAHP-EA and FAHP-GM on the other hand TR32 and TR62 are also the most attractive sub-regions with respect to FAHP-FPP with respect to the Tourism (T).

\subsection{FAHP/DEA application}

In this section, we combined priorities of qualitative data calculated by FAHP with the quantitative data for the years 2009 and 2010. The CCR and BCC efficiencies were used for ranking the NUTS-2 sub-regions with respect to two models in order to understand the effects of earthquake risk, tourism and security.

Model 1:

Inputs: Crude suicide rate (\%000), Security, Earthquake risk

Outputs: College or university graduate rate (\%), Exports per capita, Value of crop production per capita (TL), Tourism.

Model 2:

Inputs: Per capita electricity consumption (2009), Number of enterprises (2010), Security, Earthquake risk

Outputs; Literacy rate, College or university graduate rate (\%) Imports per capita, Number of benefit from the libraries thousands per capita.

The efficiency scores of DMUs, i.e. NUTS-2 sub-regions of Turkey, according to the Model 1 and Model 2, are computed by integrated FAHP/DEA method with CCR and BCC models as shown in Tables 5-6, respectively.

In Table 5, an efficiency score of " 1 " shows that a sub-region has been determined to belong to the efficient frontier group. TR10 (İstanbul) is the most efficient sub-region according to the Model 1. As shown in Table 6, the FAHP-EA/CCR model determines the following ten sub-regions TR10, TR41, TR51, TR61, TR62, TR63, TR71, TR83, TR90 and TRC3 as efficient frontiers while the FAHP-EA/BCC finds the following fifteen sub-regions TR10, TR21, TR41, TR42, TR51, TR52, TR61, TR62, TR63, TR71, TR83, TR90, TRC1, TRC2 and TRC3 for the year 2009. According to the results, we see that the FAHP-EA/ CCR model reduces the number of efficient DMUs for the Model 1.

As shown in Table 5, FAHP-GM/CCR model determines nine efficient sub-regions while the FAHP-GM/BCC model finds ten efficient sub-regions. On the other hand, FAHP-GM/ CCR model determines fourteen efficient sub-regions while the FAHP-FPP/BCC model finds sixteen sub-regions. According to the results, we see that the FAHP-GM/CCR and FAHP-GM/BCC models decrease the number of efficient DMUs. Hence, the FAHP-GM/ CCR and FAHP-GM/BCC models have better results than the other models for the year 2009. 
을

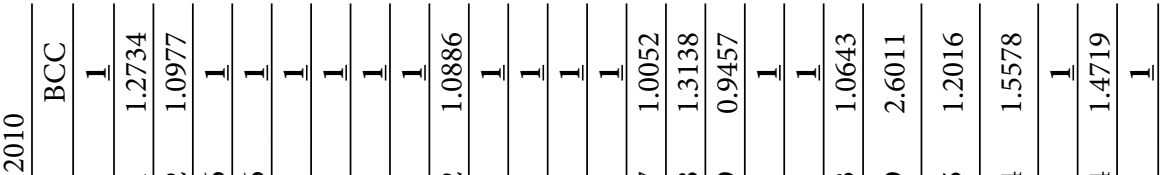

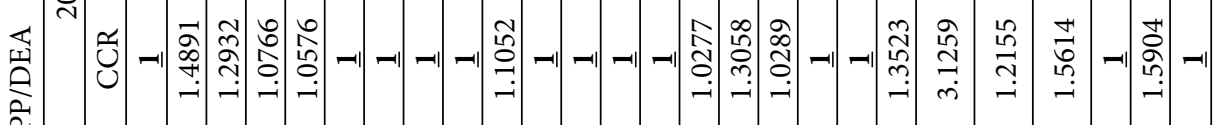

空

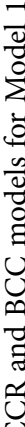

ठे

包

Uુ

○)

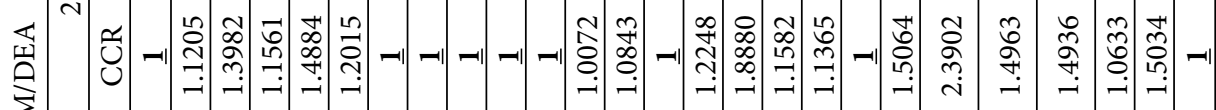

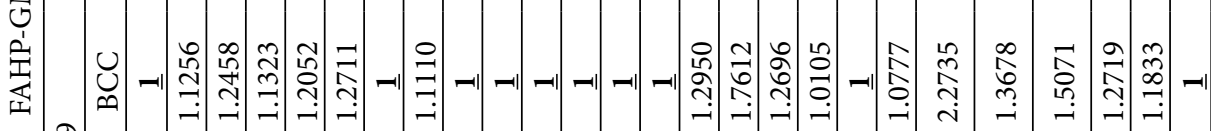
ठे

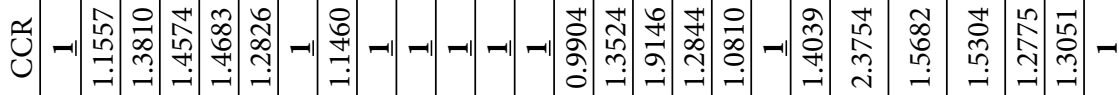

$\stackrel{\infty}{\varpi}$

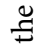

ثั)

응

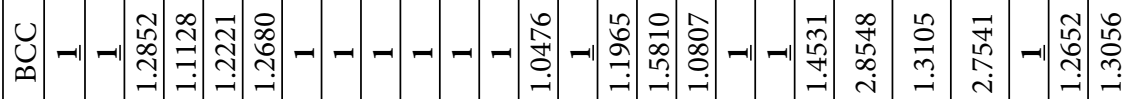

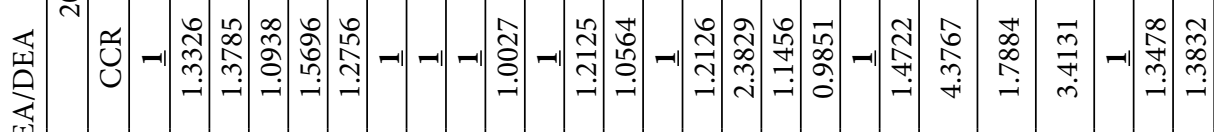

至 ஓे

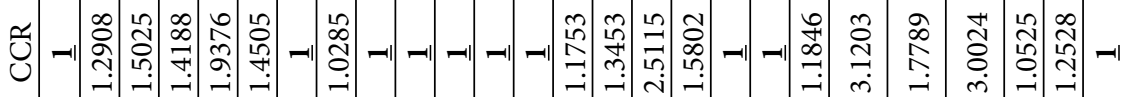

岂

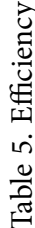

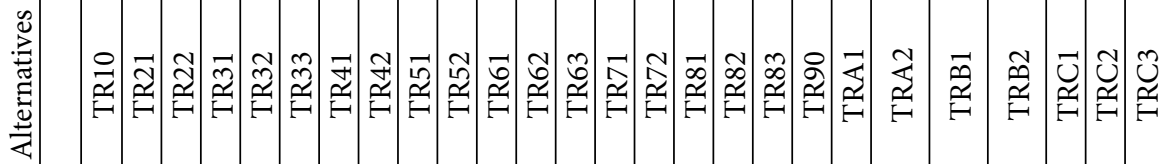




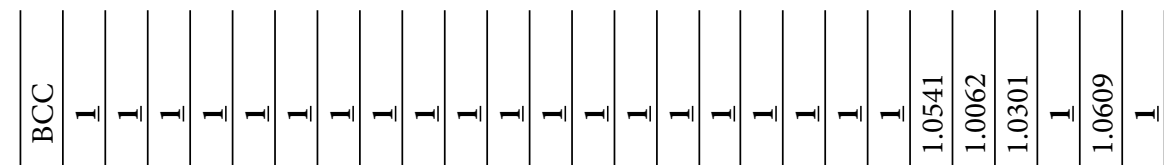

옹

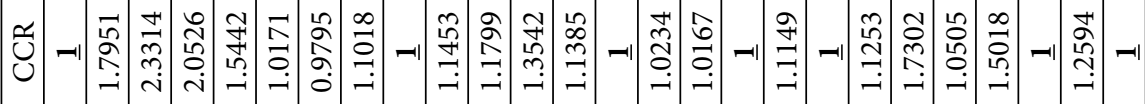

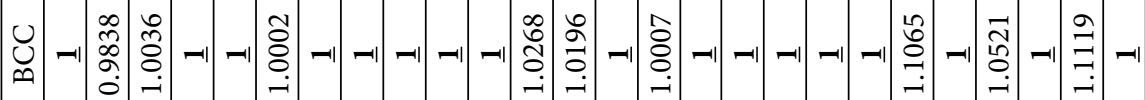

ठे̀ે

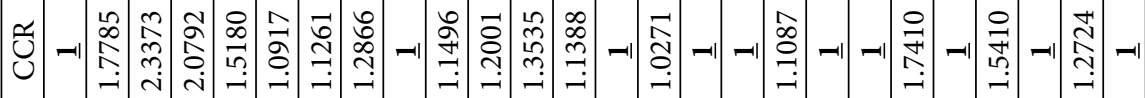

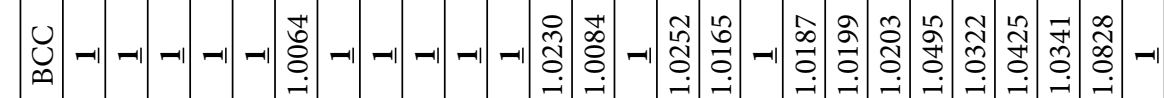

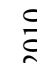

กิ

웅

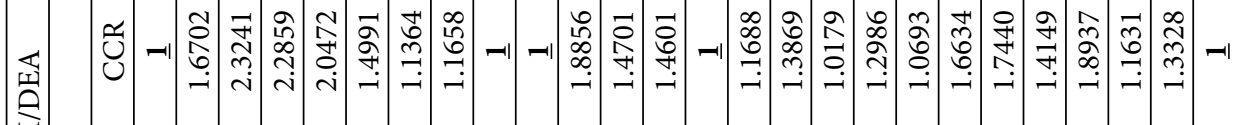

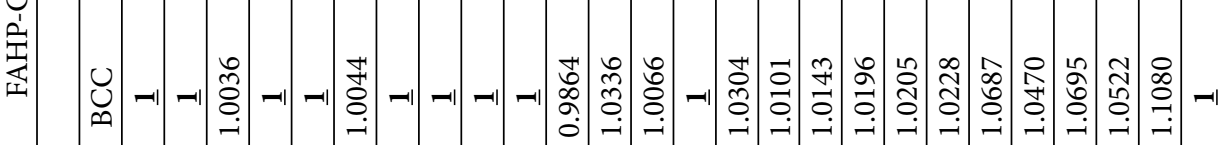$$
\stackrel{\Xi}{2}
$$$$
\Xi
$$

๖े

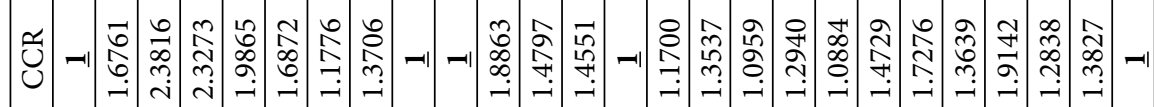

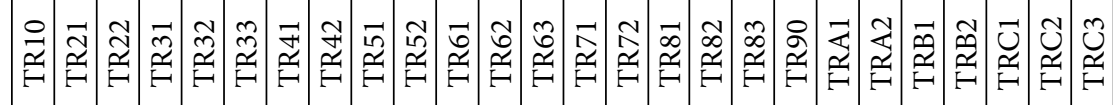


Because FAHP-EA assigns "0" value to the DMUs, we couldn't compute efficiency scores of FAHP/DEA and did not give in Table 6. In Table 6, TR10, TR51, TR52, TR71 and TRC3 are the most efficient sub-regions according to the FAHP-GM/CCR model for the year 2010. As shown in Table 6, the FAHP-GM/CCR model determines five efficient sub-regions while the FAHP-GM/BCC finds thirteen efficient sub-regions. According to the results, we see that the FAHP-GM/CCR model reduces the number of efficient DMUs for the Model 2.

As shown in Table 6, FAHP-FPP/CCR model determines seven efficient sub-regions while the FAHP-FPP/BCC model finds twenty two efficient sub-regions. According to the results, we see that the FAHP-GM/CCR and FAHP-GM/BCC models reduce the number of efficient DMUs for the data. Hence it can be concluded that the FAHP-GM/CCR and FAHP-GM/BCC models have better results than the others.

The results of our analyses have some policy implications for understanding the differences among sub-regions. The current research found 38\%, 34\%, 53\% of the 26 efficient sub-regions in the output-oriented CCR model with FAHP-EA/DEA, FAHP-GM/DEA and FAHP-FPP/DEA for the year 2009, respectively. The smallest relative efficiency scores are found for the East sub-regions (TRA1, TRA2, TRB1 etc.). This is an important outcome highlighting the disparity in socio-economic status among sub-regions in Turkey. The decision makers can improve the sub-regions' performance with higher industrial development, strong economy policies, new investment and trade policy, etc. The result of this analysis shows that the big sub-regions, $30 \%$ of the 26 sub-regions output-oriented CCR model with FAHP-EA/DEA for the year 2010, are on the efficiency frontiers. The result indicates a lower efficient performance amongst the sub-regions and it is reflected in the specific aspects in Turkey. The sub-regions of the Turkey, such as TR10, TR41, TR51, etc., have more natural resources, industries and national/international investments. Therefore, these sub-regions show efficient performances by integrated FAHP/DEA methods.

\section{Conclusions}

In this study, the ranking of the NUTS-2 sub-regions in Turkey has been obtained by integrated FAHP/DEA models for the related data for the years 2009 and 2010. For converting qualitative data to quantitative data, FAHP methods have been used. According to the decision makers' judgments, fuzzy comparison matrices have been constituted by using triangular fuzzy scale of preferences. Priorities of qualitative data have been combined with other quantitative ones. DEA method has been applied to the combined data with Model 1 and Model 2. Finally, the efficiency scores have been computed for ranking the NUTS-2 sub-regions. The results are useful for understanding the differences of sub-regions in Turkey. The results of this study show that the ranking of 26 sub-regions exhibits a divergence between different models. Thus, we pointed out that different FAHP methods affect the efficiency scores of CCR and BCC models.

The practical implication of the proposed integrated FAHP/DEA method is the usage of linguistic variables for evaluation of the qualitative criteria and construction of the fuzzy pairwise comparison matrices. The capability of FAHP is to tackle with qualitative criteria for converting them to quantitative ones. The DEA based mathematical programming techniques can successfully help researchers to measure the performance of DMUs in the pres- 
ence of qualitative and quantitative criteria. For the DEA method, the East sub-regions are the lowest ranked sub-regions while the West and Central sub-regions are ranked higher. The results of efficiency scores clearly indicate that the West and Central sub-regions perform better than the others.

Turkey was divided into 12 regions, 26 sub-regions and 81 provinces according to the (NUTS) classification, called as NUTS-1, NUTS-2 and NUTS-3, respectively. As a limitation of our study, we only focused on performance evaluation of the NUTS-2 sub-regions in Turkey. It is difficult to realize the pairwise comparison of qualitative criteria (security, earthquake risk and tourism) due to their large dimension. The process of obtaining weights of criteria and alternatives from this matrix often results in inconsistency. Based on this limitation, the calculations of the FAHP methods are very complicated and consume much time.

These research results can be used by many disciplines in Turkey for comparing the regions and sub-regions. However, the integrated approach can be also extended for the future researches by making improvements in different aspects. For instance, other types of MCDM methods such as TOPSIS, MOORA, etc. can be used and the obtained results can be compared with ours.

\section{Acknowledgements}

This research is based on the MSc thesis of the corresponding author. We wish to express our gratitude to the anonymous reviewers and associate editor for their insightful and constructive comments. In carrying out this research, the first and the second authors have been supported by the Selçuk University Scientific Research Project Fund (BAP) with grant number 12101010.

\section{References}

Abid, F.; Bahloul, S. 2011. Selected MENA countries' attractiveness to G7 investors, Economic Modelling 28: 2197-2207. https://doi.org/10.1016/j.econmod.2011.06.013

Akadiri, P. O.; Olomolaiye, P. O.; Chinyio, E. A. 2013. Multi-criteria evaluation model for the selection of sustainable materials for building projects, Automation in Construction 30: 113-125.

https://doi.org/10.1016/j.autcon.2012.10.004

Azadeh, A.; Ghaderi, S. F.; Izadbakhsh, H. 2008. Integration of DEA and AHP with computer simulation for railway system improvement and optimization, Applied Mathematics and Computation 195: 775-785. https://doi.org/10.1016/j.amc.2007.05.023

Azadeh, A.; Ghaderi, S. F.; Mirjalili, M.; Moghaddam, M. 2011. Integration of analytic hierarchy process and data envelopment analysis for assessment and optimization of personnel productivity in a large industrial bank, Expert Systems with Applications 38: 5212-5225.

https://doi.org/10.1016/j.eswa.2010.10.038

Baležentis, A.; Baležentis, T. 2011. Assessing the efficiency of Lithuanian transport sector by applying the methods of multimoora and data envelopment analysis, Transport 26(3): 263-270. https://doi.org/10.3846/16484142.2011.621146

Banker, R. D.; Charnes, A.; Cooper, W. W. 1984. Some models for estimating technical and scale inefficiencies in data envelopment analysis, Management Science 30: 1078-1092.

https://doi.org/10.1287/mnsc.30.9.1078 
Baysal, M. E.; Kaya, İ.; Kahraman, C.; Sarucan, A.; Engin, O. 2015. A two phased fuzzy methodology for selection among municipal projects, Technological and Economic Development of Economy 21(3): 405-422. https://doi.org/10.3846/20294913.2014.909902

Brauers, W. K. M.; Kildiene, S.; Zavadskas, E. K.; Kaklauskas, A. 2013. The construction sector in twenty European countries during the recession 2008-2009 - country ranking by MULTIMOORA, International Journal of Strategic Property Management 17: 58-78. https://doi.org/10.3846/1648715X.2013.775194

Buckley, J. J. 1985. Fuzzy hierarchical analysis, Fuzzy Sets and Systems 17: 233-247. https://doi.org/10.1016/0165-0114(85)90090-9

Büyüközkan, G.; Feyzioğlu, O.; Nebol, E. 2008. Selection of the strategic alliance partner in logistics value chain, International Journal of Production Economics 113: 148-158. https://doi.org/10.1016/j.ijpe.2007.01.016

Calabrese, A.; Costa, R.; Menichini, T. 2013. Using Fuzzy AHP to manage Intellectual Capital assets: an application to the ICT service industry, Expert Systems with Applications 40(9): 3747-3755. https://doi.org/10.1016/j.eswa.2012.12.081

Çalık, A. 2012. Measurement of investment efficiency of regions in Turkey via fuzzy analytical hierarchy process/data envelopment analysis in Turkish: Bulanık Analitik Hiyerarşi Süreci/Veri Zarflama Analizi ile Türkiye'de Bölgelerin Yatirim Etkinliğinin Ölçülmesi. MSc, Selçuk University.

Camanho, A. S.; Dyson, R. G. 2005. Cost efficiency measurement with price uncertainty: a DEA application to bank branch assessments, European Journal of Operational Research 161: 432-446. https://doi.org/10.1016/j.ejor.2003.07.018

Celik, E.; Gul, M.; Aydin, N.; Gumus, A. T.; Guneri, A. F. 2015. A comprehensive review of multi criteria decision making approaches based on interval type-2 fuzzy sets, Knowledge-Based Systems 85: 329-341. https://doi.org/10.1016/j.knosys.2015.06.004

Chang, D.-Y. 1996. Applications of the extent analysis method on fuzzy AHP, European Journal of Operational Research 95: 649-655. https://doi.org/10.1016/0377-2217(95)00300-2

Charnes, A.; Cooper, W. W.; Rhodes, E. 1978. Measuring the efficiency of decision making units, European Journal of Operational Research 2: 429-444. https://doi.org/10.1016/0377-2217(78)90138-8

Che, Z. H.; Wang, H. S.; Chuang, C.-L. 2010. A fuzzy AHP and DEA approach for making bank loan decisions for small and medium enterprises in Taiwan, Expert Systems with Applications 37: 7189-7199. https://doi.org/10.1016/j.eswa.2010.04.010

Chen, X.; Skully, M.; Brown, K. 2005. Banking efficiency in China: application of DEA to pre- and post-deregulation eras: 1993-2000, China Economic Review 16: 229-245.

https://doi.org/10.1016/j.chieco.2005.02.001

CIA. 2010. The world factbook available [online], [cited 20 February 2013]. Available from Internet: https://www.cia.gov/library/publications/download/download-2010

Cooper, W. W.; Seiford, L. M.; Tone, K. 2000. Data envelopment analysis: a comprehensive text with models, applications, references, and DEA-Solver software. Kluwer Academic.

Cooper, W. W.; Seiford, L. M.; Zhu, J. 2004. Handbook on data envelopment analysis. Springer. https://doi.org/10.1007/b105307

Deveci, M.; Demirel, N. Ç.; John, R.; Özcan, E. 2015. Fuzzy multi-criteria decision making for carbon dioxide geological storage in Turkey, Journal of Natural Gas Science and Engineering 27(2): 692-705. https://doi.org/10.1016/j.jngse.2015.09.004

Do, Q. H.; Chen, J.-F. 2014. A hybrid fuzzy AHP-DEA approach for assessing university performance, WSEAS Transactions on Business \& Economic 11: 386-397.

Durán, O. 2011. Computer-aided maintenance management systems selection based on a fuzzy AHP approach, Advances in Engineering Software 42: 821-829.

https://doi.org/10.1016/j.advengsoft.2011.05.023 
Düzakın, E.; Düzakın, H. 2007. Measuring the performance of manufacturing firms with super slacks based model of data envelopment analysis: an application of 500 major industrial enterprises in Turkey, European Journal of Operational Research 182: 1412-1432.

https://doi.org/10.1016/j.ejor.2006.09.036

Ecer, F. 2014. A hybrid banking websites quality evaluation model using AHP and COPRAS-G: a Turkey case, Technological and Economic Development of Economy 20(4): 758-782. https://doi.org/10.3846/20294913.2014.915596

Erol, Ö.; Kılkış, B. 2012. An energy source policy assessment using analytical hierarchy process, Energy Conversion and Management 63: 245-252. https://doi.org/10.1016/j.enconman.2012.01.040

Ertay, T.; Ruan, D.; Tuzkaya, U. R. 2006. Integrating data envelopment analysis and analytic hierarchy for the facility layout design in manufacturing systems, Information Sciences 176: 237-262. https://doi.org/10.1016/j.ins.2004.12.001

Gao, L.; Hailu, A. 2012. Ranking management strategies with complex outcomes: an AHP-fuzzy evaluation of recreational fishing using an integrated agent-based model of a coral reef ecosystem, Environmental Modelling \& Software 31: 3-18. https://doi.org/10.1016/j.envsoft.2011.12.002

Giokas, D. I.; Pentzaropoulos, G. C. 2008. Efficiency ranking of the OECD member states in the area of telecommunications: a composite AHP/DEA study, Telecommunications Policy 32: 672-685. https://doi.org/10.1016/j.telpol.2008.07.007

Govindan, K.; Khodaverdi, R.; Jafarian, A. 2013. A fuzzy multi criteria approach for measuring sustainability performance of a supplier based on triple bottom line approach, Journal of Cleaner Production 47: 345-354. https://doi.org/10.1016/j.jclepro.2012.04.014

Ho, W. 2008. Integrated analytic hierarchy process and its applications - a literature review, European Journal of Operational Research 186: 211-228. https://doi.org/10.1016/j.ejor.2007.01.004

Johnes, J. 2006. Measuring teaching efficiency in higher education: an application of data envelopment analysis to economics graduates from UK Universities 1993, European Journal of Operational Research 174: 443-456. https://doi.org/10.1016/j.ejor.2005.02.044

Kahraman, C. 2008. Fuzzy multi-criteria decision making: theory and applications with recent developments. Springer US. https://doi.org/10.1007/978-0-387-76813-7

Kahraman, C.; Ertay, T.; Büyüközkan, G. 2006. A fuzzy optimization model for QFD planning process using analytic network approach, European Journal of Operational Research 171: 390-411. https://doi.org/10.1016/j.ejor.2004.09.016

Kahraman, C.; Onar, S. C.; Oztaysi, B. 2015. Fuzzy multicriteria decision-making: a literature review, International Journal of Computational Intelligence Systems 8: 637-666. https://doi.org/10.1080/18756891.2015.1046325

Kahraman, C.; Suder, A.; Cebi, S. 2013. Fuzzy multi-criteria and multi-experts evaluation of government investments in higher education: the case of Turkey, Technological and Economic Development of Economy 19: 549-569. https://doi.org/10.3846/20294913.2013.837110

Kaya, T.; Kahraman, C. 2011. Fuzzy multiple criteria forestry decision making based on an integrated VIKOR and AHP approach, Expert Systems with Applications 38: 7326-7333. https://doi.org/10.1016/j.eswa.2010.12.003

Köksal, C. D.; Aksu, A. A. 2007. Efficiency evaluation of A-group travel agencies with data envelopment analysis (DEA): a case study in the Antalya region, Turkey, Tourism Management 28: 830-834. https://doi.org/10.1016/j.tourman.2006.05.013

Korpela, J.; Lehmusvaara, A.; Nisonen, J. 2007. Warehouse operator selection by combining AHP and DEA methodologies, International Journal of Production Economics 108: 135-142. https://doi.org/10.1016/j.ijpe.2006.12.046

Kou, M.; Chen, K.; Wang, S.; Shao, Y. 2016. Measuring efficiencies of multi-period and multi-division systems associated with DEA: an application to OECD countries' national innovation systems, Expert Systems with Applications 46: 494-510. https://doi.org/10.1016/j.eswa.2015.10.032 
Kumar, A.; Shankar, R.; Debnath, R. M. 2015. Analyzing customer preference and measuring relative efficiency in telecom sector: a hybrid fuzzy AHP/DEA study, Telematics and Informatics 32: 447-462. https://doi.org/10.1016/j.tele.2014.10.003

Lee, S. K.; Mogi, G.; Hui, K. S. 2013. A fuzzy analytic hierarchy process (AHP)/data envelopment analysis (DEA) hybrid model for efficiently allocating energy R\&D resources: in the case of energy technologies against high oil prices, Renewable and Sustainable Energy Reviews 21: 347-355. https://doi.org/10.1016/j.rser.2012.12.067

Lee, S. K.; Mogi, G.; Lee, S. K.; Hui, K. S.; Kim, J. W. 2010. Econometric analysis of the R\&D performance in the national hydrogen energy technology development for measuring relative efficiency: the fuzzy AHP/DEA integrated model approach, International Journal of Hydrogen Energy 35: 2236-2246. https://doi.org/10.1016/j.ijhydene.2010.01.009

Lee, S. K.; Mogi, G.; Li, Z.; Hui, K. S.; Lee, S. K.; Hui, K. N.; Park, S. Y.; Ha, Y. J.; Kim, J. W. 2011. Measuring the relative efficiency of hydrogen energy technologies for implementing the hydrogen economy: an integrated fuzzy AHP/DEA approach, International Journal of Hydrogen Energy 36: 12655-12663. https://doi.org/10.1016/j.ijhydene.2011.06.135

Lin, C.-T.; Lee, C.; Chen, W.-Y. 2009. Using fuzzy analytic hierarchy process to evaluate service performance of a travel intermediary, The Service Industries Journal 29: 281-296. https://doi.org/10.1080/02642060701846762

Lin, M.-I.; Lee, Y.-D.; Ho, T.-N. 2011. Applying integrated DEA/AHP to evaluate the economic performance of local governments in China, European Journal of Operational Research 209: 129-140. https://doi.org/10.1016/j.ejor.2010.08.006

Liou, J. J. H.; Tzeng, G.-H. 2012. Comments on "Multiple criteria decision making (MCDM) methods in economics: an overview", Technological and Economic Development of Economy 18(4): 672-695. https://doi.org/10.3846/20294913.2012.753489

Liu, C.-H.; Tzeng, G.-H.; Lee, M.-H. 2012. Improving tourism policy implementation - the use of hybrid MCDM models, Tourism Management 33: 413-426. https://doi.org/10.1016/j.tourman.2011.05.002

Mardani, A.; Jusoh, A.; Md Nor, K.; Khalifah, Z.; Zakwan, N.; Valipour, A. 2015. Multiple criteria decision-making techniques and their applications - a review of the literature from 2000 to 2014, Economic Research-Ekonomska Istraživanja 28: 516-571. https://doi.org/10.1080/1331677X.2015.1075139

Meng, F. Y.; Zhou, P.; Zhou, D. Q.; Bai, Y. 2014. Inefficiency and congestion assessment of mix energy consumption in 16 APEC countries by using DEA window analysis, Energy Procedia 61: 2518-2523. https://doi.org/10.1016/j.egypro.2014.12.036

Mikhailov, L. 2002. Fuzzy analytical approach to partnership selection in formation of virtual enterprises, Omega 30: 393-401. https://doi.org/10.1016/S0305-0483(02)00052-X

Mikhailov, L. 2003. Deriving priorities from fuzzy pairwise comparison judgements, Fuzzy Sets and Systems 134: 365-385. https://doi.org/10.1016/S0165-0114(02)00383-4

Najafi, A.; Karimpour, M. H.; Ghaderi, M. 2014. Application of fuzzy AHP method to IOCG prospectivity mapping: a case study in Taherabad prospecting area, eastern Iran, International Journal of Applied Earth Observation and Geoinformation 33: 142-154. https://doi.org/10.1016/j.jag.2014.05.003

Nazarko, J.; Šaparauskas, J. 2014. Application of DEA method in efficiency evaluation of public higher education institutions, Technological and Economic Development of Economy 20(1): 25-44. https://doi.org/10.3846/20294913.2014.837116

Pan, N.-F. 2008. Fuzzy AHP approach for selecting the suitable bridge construction method, Automation in Construction 17: 958-965. https://doi.org/10.1016/j.autcon.2008.03.005

Ramanathan, R. 2006a. Data envelopment analysis for weight derivation and aggregation in the analytic hierarchy process, Computers \& Operations Research 33: 1289-1307.

https://doi.org/10.1016/j.cor.2004.09.020 
Ramanathan, R. 2006b. Evaluating the comparative performance of countries of the Middle East and North Africa: a DEA application, Socio-Economic Planning Sciences 40: 156-167. https://doi.org/10.1016/j.seps.2004.10.002

Saaty, T. L. 1980. The analytic hierarchy process: planning, priority setting, resource allocation. McGrawHill.

Saen, R. F.; Memariani, A.; Lotfi, F. H. 2005. Determining relative efficiency of slightly non-homogeneous decision making units by data envelopment analysis: a case study in IROST, Applied Mathematics and Computation 165: 313-328. https://doi.org/10.1016/j.amc.2004.04.050

Sarica, K.; Or, I. 2007. Efficiency assessment of Turkish power plants using data envelopment analysis, Energy 32: 1484-1499. https://doi.org/10.1016/j.energy.2006.10.016

Sevkli, M.; Lenny Koh, S. C.; Zaim, S.; Demirbag, M.; Tatoglu, E. 2007. An application of data envelopment analytic hierarchy process for supplier selection: a case study of BEKO in Turkey, International Journal of Production Research 45: 1973-2003. https://doi.org/10.1080/00207540600957399

Shafer, S. M.; Byrd, T. A. 2000. A framework for measuring the efficiency of organizational investments in information technology using data envelopment analysis, Omega 28: 125-141. https://doi.org/10.1016/S0305-0483(99)00039-0

Shaw, K.; Shankar, R.; Yadav, S. S.; Thakur, L. S. 2012. Supplier selection using fuzzy AHP and fuzzy multi-objective linear programming for developing low carbon supply chain, Expert Systems with Applications 39: 8182-8192. https://doi.org/10.1016/j.eswa.2012.01.149

Sinuany-Stern, Z.; Mehrez, A.; Hadad, Y. 2000. An AHP/DEA methodology for ranking decision making units, International Transactions in Operational Research 7: 109-124.

https://doi.org/10.1111/j.1475-3995.2000.tb00189.x

Sözen, A.; Alp, İ.; Özdemir, A. 2010. Assessment of operational and environmental performance of the thermal power plants in Turkey by using data envelopment analysis, Energy Policy 38: 6194-6203. https://doi.org/10.1016/j.enpol.2010.06.005

Sun, J. H.; Hu, J.; Yan, J. M.; Liu, Z.; Shi, Y. R. 2012. Regional environmental performance evaluation: a case of western regions in China, Energy Procedia 16(Part A): 377-382. https://doi.org/10.1016/j.egypro.2012.01.062

Tansel Iç, Y.; Yurdakul, M.; Dengiz, B. 2013. Development of a decision support system for robot selection, Robotics and Computer-Integrated Manufacturing 29: 142-157. https://doi.org/10.1016/j.rcim.2012.11.008

Taylan, O.; Bafail, A. O.; Abdulaal, R. M. S.; Kabli, M. R. 2014. Construction projects selection and risk assessment by fuzzy AHP and fuzzy TOPSIS methodologies, Applied Soft Computing 17: 105-116. https://doi.org/10.1016/j.asoc.2014.01.003

Thokala, P.; Duenas, A. 2012. Multiple criteria decision analysis for health technology assessment, Value in Health 15: 1172-1181. https://doi.org/10.1016/j.jval.2012.06.015

Tseng, Y.-F.; Lee, T.-Z. 2009. Comparing appropriate decision support of human resource practices on organizational performance with DEA/AHP model, Expert Systems with Applications 36: 65486558. https://doi.org/10.1016/j.eswa.2008.07.066

Tzeng, G. H.; Huang, J. J. 2011. Multiple attribute decision making: methods and applications. Taylor \& Francis.

Vaidya, O. S.; Kumar, S. 2006. Analytic hierarchy process: an overview of applications, European Journal of Operational Research 169: 1-29. https://doi.org/10.1016/j.ejor.2004.04.028

Van Laarhoven, P. J. M.; Pedrycz, W. 1983. A fuzzy extension of Saaty's priority theory, Fuzzy Sets and Systems 11: 229-241. https://doi.org/10.1016/S0165-0114(83)80082-7

Vlontzos, G.; Niavis, S.; Manos, B. 2014. A DEA approach for estimating the agricultural energy and environmental efficiency of EU countries, Renewable and Sustainable Energy Reviews 40: 91-96. https://doi.org/10.1016/j.rser.2014.07.153 
Wang, K.; Yu, S.; Zhang, W. 2013. China's regional energy and environmental efficiency: a DEA window analysis based dynamic evaluation, Mathematical and Computer Modelling 58: 1117-1127. https://doi.org/10.1016/j.mcm.2011.11.067

Wang, Y.-M.; Liu, J.; Elhag, T. M. S. 2008. An integrated AHP-DEA methodology for bridge risk assessment, Computers \& Industrial Engineering 54: 513-525. https://doi.org/10.1016/j.cie.2007.09.002

WIKIPEDIA. 2014. Economy of Turkey [online], [cited 15 February 2014]. Available from Internet: https://en.wikipedia.org/wiki/Economy_of_Turkey

WIKIPEDIA. 2015. Nomenclature of territorial units for statistics [online], [cited 01 July 2014]. Available from Internet: http://en.wikipedia.org/wiki/Nomenclature_of_Territorial_Units_for_Statistics

Yang, G.; Ahlgren, P.; Yang, L.; Rousseau, R.; Ding, J. 2016. Using multi-level frontiers in DEA models to grade countries/territories, Journal of Informetrics 10: 238-253.

https://doi.org/10.1016/j.joi.2016.01.008

Yang, T.; Kuo, C. 2003. A hierarchical AHP/DEA methodology for the facilities layout design problem, European Journal of Operational Research 147: 128-136. https://doi.org/10.1016/S0377-2217(02)00251-5

Zavadskas, E. K.; Skibniewski, M. J.; Antucheviciene, J. 2014a. Performance analysis of Civil Engineering Journals based on the Web of Science ${ }^{\star}$ database, Archives of Civil and Mechanical Engineering 14: 519-527. https://doi.org/10.1016/j.acme.2014.05.008

Zavadskas, E. K.; Turskis, Z. 2011. Multiple criteria decision making (MCDM) methods in economics: an overview, Technological and Economic Development of Economy 17: 397-427. https://doi.org/10.3846/20294913.2011.593291

Zavadskas, E. K.; Turskis, Z.; Kildienė, S. 2014b. State of art surveys of overviews on MCDM/MADM methods, Technological and Economic Development of Economy 20(1): 165-179.

https://doi.org/10.3846/20294913.2014.892037 